\title{
Identification of Paraneurons by Labelling with Quinacrine (Atebrin)*
}

\author{
Peter Böck \\ Department of Anatomy (Prof. F. Hammersen), Technical University Munich, Munich, Federal \\ Republic of Germany
}

Received July 31, 1979

\begin{abstract}
Summary. Quinacrine (Atebrin), an antimalarial drug that binds to adenine nucleotides, was used to label paraneurons. The drug was dissolved in physiological saline and intraperitoneally injected (rats, mice, guinea pigs) in concentrations of $120 \mathrm{or} 200 \mathrm{mg} / \mathrm{kg}$ body weight. The animals were killed three days later and paraneurons were studied in the fluorescence microscope after freeze drying. Bright fluorescence is observed in adrenomedullary cells, SIF cells, carotid body chief cells, pancreatic islet cells, anterior pituitary cells, pinealocytes, and mast cells. Weak fluorescence occurs in thyroid parafollicular cells, Merkel cells, and a few entero-endocrine cells. It is suggested that quinacrine binds to ATP or related adenine nucleotides which are stored in secretory granules of paraneurons. Varying fluorescence intensity seems to depend on different concentrations of adenine nucleotides within the storage granules, as well as on the different size and number of these granules in various paraneurons. Besides formaldehyde-induced fluorescence of biogenic amines, $\mathrm{HCl}$-basic dye staining methods and electron microscopy, the method is useful to identify and define paraneurons.
\end{abstract}

Paraneurons, as defined by FujiTa $(1976,1977)$, are "receptosecretory cells" which share the following characteristics:

1. Synthesis of identified or suspected neurotransmitter substances,

2. Synthesis of proteins and/or peptides of identified or suspected hormonal activity,

3. Storage of the above mentioned substances within subcellular vesicles of characteristic fine structure (synaptic type vesicles, dense core vesicles, neurosecretion granules),

4. Recepto-secretory function, i.e. the cell secretes its products in response to a specific stimulus, and

5. Origin from the neuroectoderm (FuJITA, 1977; this ontogenic item as the criterion of paraneurons was abandoned in FuJITA's later paper: FUJITA and KoBAYASHI, 1979).

The concept of paraneurons includes the APUD-cell concept of PEARSE (1969).

Identification of paraneurons is mainly based on the fine structural observation of vesicles or granules which are believed to store the specific products (item 3 ),

* Supported by the "Deutsche Forschungsgemeinschaft," grant Nr. Bo 525/3. 
or on the demonstration of catechol- or indolamines, eventually histamine, based on the sensitive fluorescence method of FALCK (1962; item 1). Other methods are assumed to show peptide hormones or carrier proteins (item 2): staining with basic dyes (Solcia et al., 1968a) or with Coriphosphine O (Bussol ATI et al., 1969) after Feulgentype hydrolysis, or staining with lead hematoxylin (Solcia et al., 1968b). Obviously only the use of all these techniques will yield a representive impression of a paraneuron.

As to item 3, the presence of ATP and other adenine nucleotides has been demonstrated in subcellular granules of adrenomedullary cells (WINKLER et al., 1972), of pancreatic islet cells (LEITNER et al., 1975), and of gastro-enteric endocrine cells (BAKER, 1959). FuJita (1976) suggests that "the occurrence of ATP and other adenine nucleotides.... is now likely to be common for every paraneuronic cell." The present paper offers evidence to establish this hypothesis.

\section{MATERIAL AND METHODS}

\section{Fluorescence microscopy}

Adult Swiss mice, Sprague-Dawley rats, and wild type guinea pigs of either sex were used in this study. The animals received an intraperitoneal injection of quinacrine hydrochloride (Serva, Heidelberg), either 120 or $200 \mathrm{mg} / \mathrm{kg}$, dissolved in physiological saline. One or three days later the animals were anesthetized with ether and the following organs were removed: suprarenal gland, carotid body (carotid bifurcation), thyroid and parathyroid gland, pituitary and pineal gland, skin with sinus hairs, fundus and pylorus of the stomach, duodenum and rectum, lymph nodes and spleen, salivary glands, pancreas, liver, kidney, and skeletal muscle. The tissues were quenched in isopentane cooled with liquid nitrogen and sectioned at $15 \mu \mathrm{m}$ in a cryomicrotome. Frozen sections were collected and brought into a freeze-drying apparatus (model GT1 Leybold-Heraeus, Cologne) and dried at $-30^{\circ} \mathrm{C}$ for $12 \mathrm{hrs}$ (HeEne, 1968). The dried sections were mounted in paraffin oil and studied in a Leitz fluorescence microscope equipped with epillumination (higher magnification, objective $\times 40$ ) and darkfield illumination (lower magnification). A HBO 200 high pressure mercury lamp, a Schott BG 12 excitor filter, and a K 515 barrier filter were used.

\section{Electron microscopy}

Swiss mice were anesthetized with ether and fixed by perfusion with $3 \%$ glutaraldehyde in $0.1 \mathrm{M}$ cacodylate buffer, $\mathrm{pH} 7.2$, for $5 \mathrm{~min}$. Thereafter the adrenal and pituitary glands and the carotid bifurcation were removed and fixed for additional $2 \mathrm{hrs}$ in the same solution. The specimens were washed in $0.9 \% \mathrm{NaCl}$, reduced to small slices with razor blades and kept for $12 \mathrm{hrs}$ in a $4 \%$ aqueous solution of uranyl acetate ( $\mathrm{pH}$ 3.9): uranaffin reaction (RICHARDS and DA PRADA, 1977). After this treatment the tissues were washed in $0.9 \% \mathrm{NaCl}$, dehydrated in a series of ethanol and embedded in Araldite. Semithin and thin sections were cut on a Reichert OmU2 ultramicrotome and studied in a Zeiss EM 9 electron microscope, either without further staining or after a short staining with alkaline lead citrate (REY NOLDS, 1963). 


\section{RESULTS}

Fluorescence microscopical results are compiled in Table 1.

Table 1. Quinacrine fluorescence of paraneurons, 3 days after a single intraperitoneal injection of $200 \mathrm{mg} / \mathrm{kg}$ of the drug

\begin{tabular}{|c|c|c|}
\hline Paraneurons ${ }^{1)}$ & Fluorescence intensity ${ }^{2)}$ & Comments \\
\hline a Adrenal chromaffin cell & HH M, R, GP & $\begin{array}{l}\text { Fig. } 4 \text {; differences between } \\
\text { A and NA cells? }\end{array}$ \\
\hline b SIF cell & H M, R, GP & Fig. 13 \\
\hline c Carotid body chief cell & H $M, H R, G P$ & Fig. 13 \\
\hline d Parafollicular cell & $\pm /+\mathrm{M}, \mathrm{R}, \mathrm{GP}$ & \\
\hline e Parathyroid cell & & \\
\hline f Anterior pituitary cell & HI M, R, GP & 3), Fig. 9, 10 \\
\hline g Pancreatic islet cell & H M, R, GP & $A$ and $B$ cells, Fig. 1, 2 \\
\hline h Intestinal basal granulated cell & $-? / \pm$ a few $+M, R, G P$ & $\begin{array}{l}\text { Fig. } 6 \text {, only duodenum and } \\
\text { rectum were studied }\end{array}$ \\
\hline i Gustatory cell & not observed & \\
\hline j Bronchial basal granulated cell & not observed & \\
\hline $\begin{array}{l}\mathrm{k} \text { Hair cell of the inner ear, } \\
\text { lateral line organ }\end{array}$ & & \\
\hline $\begin{array}{l}\text { Retinal photoreceptor cell, } \\
\text { pinealocyte of birds }\end{array}$ & not studied & see $r$ \\
\hline m Olfactory cell & not studied & \\
\hline $\mathrm{n}$ Liquor contacting neuron & not studied & \\
\hline o Merkel cell & $+\mathrm{M}, \mathrm{R}$ & $\begin{array}{l}\text { see also CROWE and WHITEAR } \\
1978\end{array}$ \\
\hline $\mathrm{p}$ Melanocyte of fish & not studied & 4) \\
\hline q Mast cell & HI M, R, GP & Fig. 7, 13 \\
\hline$r$ Pinealocyte of mammals & H M, R, GP & 5), Fig. 3 \\
\hline
\end{tabular}

1) Paraneurons are listed according to Fig. 1 from Fujita (1976).

2) Fluorescence intensity is given in arbitrary units:,,,- \pm++ and $H ; M=$ mouse, $R=$ rat, $\mathrm{GP}=$ guinea pig.

3) Obviously fluorescence intensity is different in the various cell types. Definite classification remains to be done.

4) Melanocytes in the GP appear black, also background fluorescence is suppressed by melanine. Thus eventually existing labelling with quinacrine can not be observed.

5) Mammalian pinealocytes are listed separately because they do not include photoreceptor structures.

As to the fluorescence intensity of paraneurons, no significant differences were observed between animals injected with $120 \mathrm{mg} / \mathrm{kg}$ of quniacrine and those which received $200 \mathrm{mg} / \mathrm{kg}$. However, as a technical comment, it is recommended to inject $200 \mathrm{mg} / \mathrm{kg}$ of quinacrine and to wait 2 or 3 days before killing the animals. During this time about $30 \%$ of the drug is excreted (Rollo, 1970) and diffuse fluorescence of 

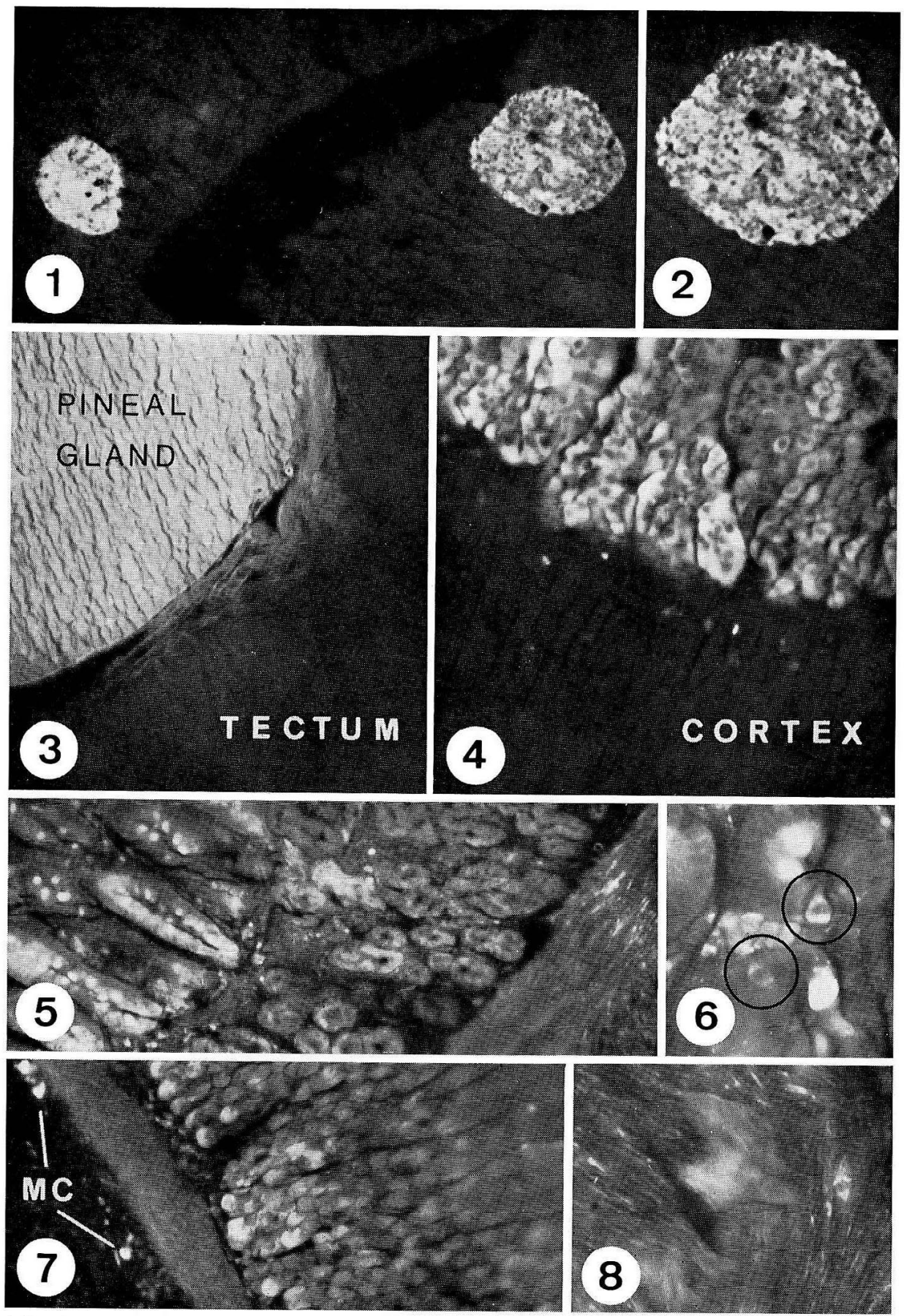

Fig. 1-8. Legends on the opposite page. 
the background or fluorescence of the ergastoplasm is markedly diminished (compare Fig. 1-4 and 5-8). This allows better discernment of those cells which selectively accumulate the drug.

Besides binding of quinacrine to plasma proteins, DNA and RNA, an affinity of the drug to some polysaccharides is observed, e.g. to the secretion of goblet cells in the duodenum (Fig. 5) or to basal lamina material of smooth muscle cells (Fig. 8). In the latter case this behavior makes it difficult to discern peptidergic axons in the wall of the gut. Nerve cell bodies, on the other hand, are clearly seen to fluoresce both in the myenteric (Fig. 8) and submucous plexus. Also mitochondria become faintly fluorescent after quinacrine treatment. This is evident in the case of cells rich in mitochondria, e.g. oxyntic cells in the fundic mucosa (Fig. 7). Also the characteristic distribution of mitochondria in various types of skeletal muscle fibers serves as an example in this direction. There is also a faint fluorescence of secretory granules in fundus glands or in the exocrine pancreas. These observations suggest binding of small amounts of quinacrine to every protein. However, during the first three days after injection of the drug all these phenomena disappear or become significantly reduced, while the labelling of paraneurons persists. Also the fluorescence of lysosomes and residual bodies seems not to be diminished during this time, but these organelles are easily discerned.

In the electron microscope specific granules of NA-storing adrenomedullary cells and of SIF cells display high electron density after applying the uranaffin reaction (c.f. Richards and DA PRADA, 1977; RichaRDS, 1978). This is also the case with the carotid body chief cells (Fig. 14). Secretory granules in anterior pituitary cells show enhanced electron opacity (Fig. 11,12) but their matrices appear by far less dense than that of specific granules mentioned above. Considering the fluorescence intensity of the respective paraneurons after quinacrine labelling, a certain discrepancy becomes apparent. Because of these and other reasons (see Discussion) experiments with the uranaffin reaction were not pursued.

\section{DISCUSSION}

The antimalarial drug quinacrine is known to be intercalated into DNA, thus inhibiting DNA- and RNA-polymerases. Binding of the drug to t-RNA and to ribosomes also has been shown (RoLlo, 1970). Quinacrine is known to accumulate in the adrenal medulla where it has been identified by means of fluorescence microscopy (OLson et al., 1976). Quinacrine has been shown to bind to a population of nerve fibers in the

Fig. 1-4. Quinacrine fluorescence of pancreatic islet cells $(\mathbf{1}, \mathbf{2})$, pinealocytes (3), and adrenomedullary cells $(4)$ in the mouse, three days after a single intraperitoneal injection of $200 \mathrm{mg} / \mathrm{kg}$ of quinacrine. Paraneurons are brightly fluorescent under these conditions, no background fluorescence is observed. $1: \times 90 ; 2: \times 140 ; 3: \times 90 ; 4: \times 220$

Fig. 5-8. Quinacrine fluorescence in rat tissue, one day after a single intraperitoneal injection of $120 \mathrm{mg} / \mathrm{kg}$ of quinacrine. The figures show duodenal mucosa (5), duodenal crypt epithelium (6), fundic mucosa (7) and Auerbach's plexus in the duodenum (8). Enteroendocrine cells $(6$, encircled regions), mast cells $(7, M C)$, and intramural ganglion cells (8) are seen to fluoresce. However, diffuse cytoplasmic fluorescence of intestinal epithelial cells, relatively strong fluorescence of oxyntic cells, or fluorescence of goblet cells obscure the picture. $5: \times 140 ; 6: \times 350 ; 7: \times 140 ; 8: \times 220$ 

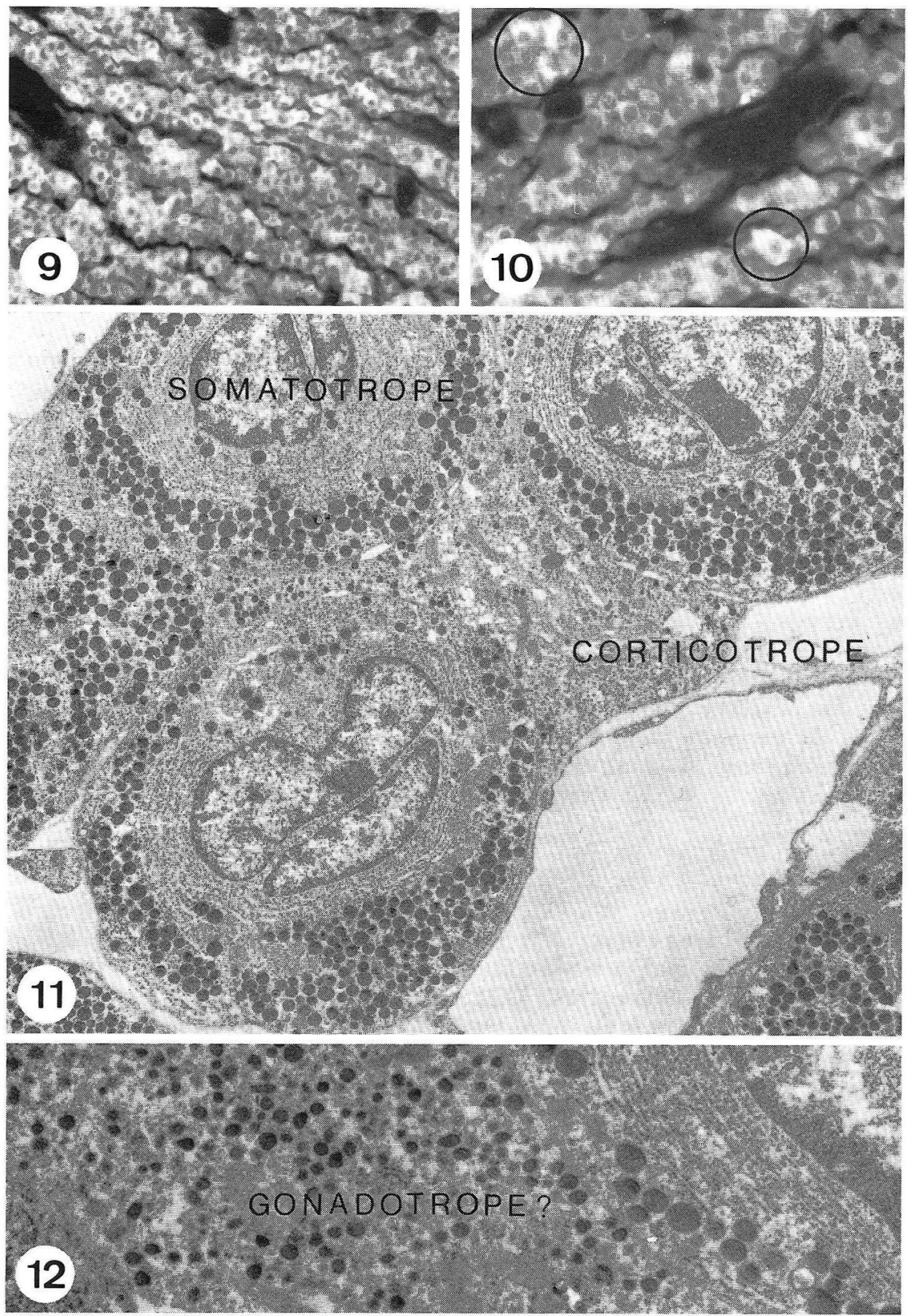

Fig. 9-12. Legends on the opposite page. 
gastro-intestinal tract (OLson et al., 1976), most probably to purinergic terminals (as defined by BuRNSTOCK, 1972). ATP or some closely related purine nucleotides are assumed as transmitter substances for these nerves. The concentrations of purine nucleotides in purinergic terminals obviously are high enough to bind sufficient amounts of quinacrine to be visualized in the fluorescence microscope (OLson et al, 1976).

Fujita (1976) suggested that ATP or a related compound may be stored in paraneurons. Actually some members of this cell series already have been shown to fulfill this concept: adrenomedullary cells (biochemically: WINKLER, 1976; histochemically: OLson et al., 1976), pancreatic islet cells (biochemically: LeITNER et al., 1975), and Merkel cells (histochemically: CROWe and Whitear, 1978). Quinacrine binding, as a histochemical method, has been used successfully in the present study to label these and other paraneuronic cells. Particularly strong fluorescence could be observed in the pineal and pituitary glands, as well as in mast cells. These findings complete and further establish the concept of paraneurons.

The weak labelling of entero-endocrine cells with quinacrine is surprising and cannot be interpreted as yet. Quenching of quinacrine fluorescence by melanine prevents the demonstration of possibly occurring labelling of melanine granules. Studies on amelanotic melanomas may furnish conclusive results in this direction. The absence of quinacrine labelling in parathyroid cells parallels the absence of catecholamine fluorescence.

It is necesssary to recall that a given paraneuron displays different reactivity when investigated with the various methods proposed to analyse this cell series. As an example, pancreatic islet cells of most species do not show catecholamine fluorescence but strongly stain with $\mathrm{HCl}$-basic dye methods, and are labelled with quinacrine. Enterochromaffin cells, by contrast, show strong indolamine fluorescence but only weak staining with $\mathrm{HCl}$-basic dye methods, and weak labelling with quinacrine. Parafollicular cells display weak catecholamine fluorescence, strong reactivity with lead hematoxyline but weak quinacrine fluorescence, and so on. All permutations seem to occur. The following interpretation tentatively is suggested: storage organelles in paraneurons contain acidic proteins or acidic peptides, ATP, and sulphomucopolysaccharides (negatively charged molecules), as well as biogenic amines (positively charged molecules). Varying amounts of these constituents are combined within a specific granulum of a paraneuron, the only restriction is to avoid a final net charge.

Histochemical methods are available for the demonstration of biogenic amines and ATP (relatively specific ones), as well as for a rough estimation of negatively charged groups. These methods yield only poor information which does not allow

Fig. 9-12. Anterior lobe of mouse pituitary gland as seen three days after a single intraperitoneal injection of $200 \mathrm{mg} / \mathrm{kg}$ of quinacrine $(\mathbf{9}, \mathbf{1 0})$ in the fluorescence microscope, and in the electron microscope after applying the uranaffin reaction in untreated animals $(\mathbf{1 1}, \mathbf{1 2})$. Anterior pituitary cells display bright fluorescence, being labelled with quinacrine. A few of the endocrine cells are conspicuously stronger fluorescent than others (10, encircled regions, probably basophilic cells?). Fixation with uranium ions enhances electron density of secretory granules, as well as electron opacity of ribosomes and chromatin $(11,12$, no counterstaining of the sections). However, secretory granules appear less dense than chromaffin granules in adrenomedullary NA-cells, though both tissues are strongly labelled with quinacrine. $9: \times 140 ; 10: \times 220 ; 11: \times 6,600 ; 12: \times 16,000$ 


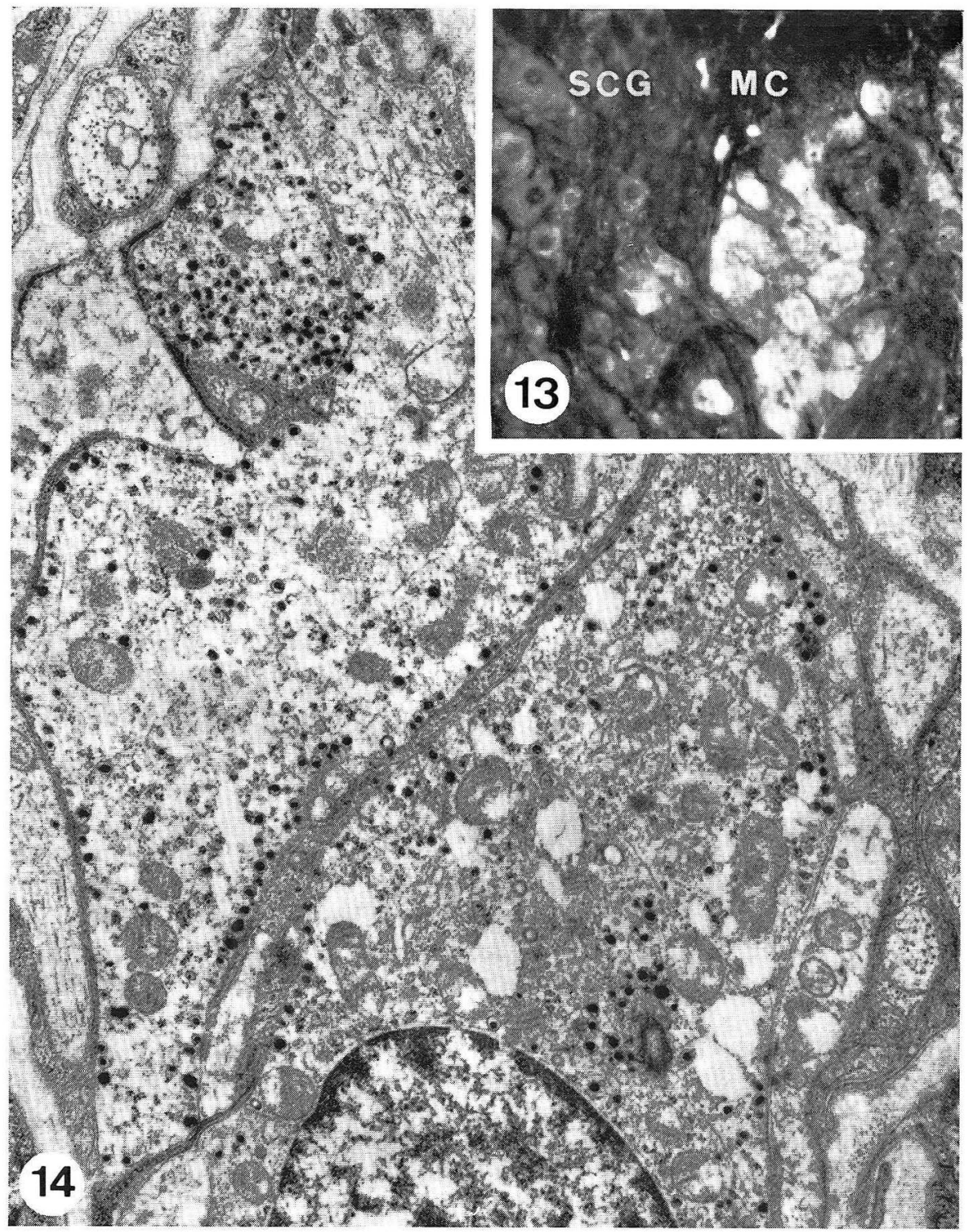

Fig. 13 and 14. Mouse carotid body as seen in the fluorescence microscope (13) three days after a sigle intraperitoneal injection of $200 \mathrm{mg} / \mathrm{kg}$ quinacrine, and in the electron microscope after applying the uranaffin reaction in untreated animals (14). Bright quinacrine fluorescence is seen in carotid body chief cells and in mast cells $(M C)$; sympathetic ganglion cells in the superior cervical ganglion (SCG) are by far less fluorescent (13). Chromatin, ribosomes and specific granules in carotid body chief cells appear electron dense after fixation with uranyl acetate. Tissue preservation is fairly good (14, short staining with lead citrate). $13: \times 220 ; 14: \times 10,000$ 
more detailed speculations.

At the fine structural level uranium ions have been suggested to bind specifically to adenine nucleotides (RICHARds and DA PradA, 1977). However, Figure 17 of the quoted paper shows part of an adrenomedullary cell interpreted to store adrenaline, the granules of which display no uranaffin reaction. A few granules of this and another adjacent cell are electron opaque and thought to store noradrenaline. It follows that the uranaffin reaction shows adenine nucleotides only in NA-storing granules and, in addition, that the authors assume also adrenomedullary A-cells to contain NA-granules. Based on our experience in typing adrenomedullary cells (GoRGAS and Böck, 1976) we feel that the chemical background of the uranaffin reaction needs further investigation. Uranium ions, as heavy metals in general, may undergo unspecific reactions with proteins, which obscure a possibly existing specific binding to adenine nucleotides. On the other hand, it seems unlikely that adrenaline storing granules are free of adenine nucleotides. Basic experiments to determine the molar ratio of catecholamine to ATP were done with ox adrenomedullary tissue, where adrenaline represents about $74 \%$ of the total catecholamine content (HolzBAUER and Sharman, 1972). Measuring the catecholamine and ATP content in six fractions from a sucrose density gradient of ox adrenomedullary tissue, BANKs (1964) reported higher percentages of total ATP in a fraction (4) which contained only half the amount of noradrenalin than the following fraction. These data cast some doubt on the specificity of the uranaffin reaction.

Acknowledgement. The author gratefully acknowledges the financial support by Bayropharm, Cologne to cover the charges for printing.

\section{REFERENCES}

Baker, R. V.: Mitochondria and storage granules for 5-hydroxytryptamine. J. Physiol. (Lond.) 145: 473-481 (1959).

Banks, P.: A study of the biochemical pharmacology of the chromaffin cell. D. Phil. Thesis, University of Oxford (1964).

Burnstock, G.: Purinergic nerves. Pharmacol. Rev. 24: 509-581 (1972).

Bussolati, G., F. W. D. Rost and A. G. E. Pearse: Fluorescence metachromasia in polypeptidehormone producing cells of the APUD series, and its significance in relation to the structure of the precursor protein. Histochem. J. 1: 517-530 (1969).

Crowe, R. and M. Whitear: Quinacrine fluorescence of Merkel cells in Xenopus laevis. Cell Tiss. Res. 190: 273-283 (1978).

Falck, B.: Observations on the possibilities of the cellular localization of monoamines by a fluorescence method. Acta physiol. scand. 56 (Suppl. 197): 1-25 (1962).

Fujita, T.: The gastro-enteric endocrine cell and its paraneuronic nature. In: (ed. by) R. E. Coupland and T. Fujita: Chromaffin, enterochromaffin and related cells. Elsevier, Amsterdam, 1976 (p. 191-208).

- : Concept of paraneurons. Arch. histol. jap. 40 (Suppl.): 1-12 (1977).

Fujita, T. and S. Kobayashi : Current views on the paraneuron concept. Trends Neurosci. 2: 2730 (1979).

Gorgas, K. and P. Böck : Morphology and histochemistry of the adrenal medulla. I. Various types of primary catecholamine-storing cells in the mouse adrenal medulla. Histochemistry 50: 17-31 (1976). 
Heene, R.: Histochemischer Nachweis von Katecholaminen und 5-Hydroxytryptamin am Kryostatschnitt. Histochemie 14: 324-327 (1968).

Holzbauer, M. and D. F. Sharman: The distribution of catecholamines in vertebrates. In: (ed. by) H. Blaschko and E. Muscholl: Catecholamines. Springer Verlag, Berlin-Heidelberg-New York, 1972 (p. 110-185).

Leitner, J. W., K. E. Sussmann, A. E. Vatter and F. H. Schneider: Adenine nucleotides in the secretory granule fraction of rat islets. Endocrinology 96: 662-677 (1975).

Olson, L., M. Ålund and K. -A. Norberg: Fluorescence-microscopical demonstration of a population of gastro-intestinal nerve fibres with a selective affinity for quinacrine. Cell Tiss. Res. 171: 407-423 (1976).

Pearse, A. G. E.: The cytochemistry and ultrastructure of polypeptide hormone-producing cells of the APUD series and the embryologic, physiologic and pathologic implications of the concept. J. Histochem. Cytochem. 17: 303-313 (1969).

Richards, J. G.: Cytochemistry and autoradiography in the search for transmitter-specific neuronal pathways. In: (ed. by) R. E. Coupland and W. G. Forssmann: Peripheral neuroendocrine interaction, Springer-Verlag, Berlin-Heidelberg-New York, 1978 (p. 1-14).

Richards, J. G. and M. Da Prada: Uranaffin reaction: a new cytochemical technique for the localization of adenine nucleotides in organelles storing biogenic amines. J. Histochem. Cytochem. 25: 1322-1336 (1977).

Reynolds, E. S.: The use of lead citrate at high $\mathrm{pH}$ as an electron-opaque stain in electron microscopy. J. Cell Biol. 17: 210-213 (1963).

Rollo, I. M.: Drugs used in the chemotherapy of malaria. In: (ed. by) L. S. Goodman and A. Gilman: The pharmacological basis of therapeutics, 4th ed. Collier McMillan Ltd., London, 1970 (p. 1095-1124).

Solcia, E., C. Capella and G. Vassallo: Lead haematoxylin as a stain for endocrine cells. Significance of staining and comparison with other selective methods. Histochemie 20:116-126 (1968a).

Solcia, E. C., G. Vassallo and C. Capella : Selective staining of endocrine cells by basic dyes after acid hydrolysis. Stain Technol. 43: 257-263 (1968b).

Winkler, H.: The composition of adrenal chromaffin granules: an assessment of controversial results. Neuroscience 1: 65-80 (1976).

Winkler, H., J. A. Schöpf, H. Hörtnagl and H. Hörtnagl : Bovine adrenal medulla: subcellular distribution of newly synthesised catecholamines, nucleotides and chromogranins. NaunynSchmiedeberg's Arch. Pharmacol. 273: 43-61 (1972).

Prof. Dr. Peter Böck

Department of Anatomy

Technical University

Biedersteinerstraße 29

D-8000 München 40

Federal Republic of Germany 